\title{
National branding strategy and its effects on business and tourism
}

\author{
Nicolae Al. POP \\ Bucharest University of Economic Studies, Bucharest, Romania \\ nicolae_al_pop@yahoo.com \\ Cristina Andrada BABA \\ Bucharest University of Economic Studies, Bucharest, Romania \\ baba.andrada@gmail.com \\ Raluca NĂSTASE ANYSZ \\ Bucharest University of Economic Studies, Bucharest, Romania \\ raluca.nastase.anysz@gmail.com \\ Dragos TOHANEAN \\ Bucharest University of Economic Studies, Bucharest, Romania \\ tohanean_dragos@yahoo.com
}

\begin{abstract}
Branding is the process through which a products' or a services' brand image is changed or is being developed. Over time, the branding process was approached from many perspectives to serve different purposes, therefore the nation branding was introduced to create a recognizable image for a country, which started to grow year by year. The scope back then, was the same as now, meaning to consolidate a nation's position in a competitive environment and to improve its reputation. A positive national image contributes to the economic growth by building up a touristic national brand, attracting foreign investors, building trust in the national companies and brands, it encourages exports, develops the public diplomacy and slows down emigration. A good national branding is advantageous for all parties involved, for the private and the public sector, as well as for all bodies and citizens, and these same parties play an important role in building it. While all parties involved are conscious about the need of a coherent brand and are willing to contribute to the branding process, it is actually a challenge to build functional models to implement it and facilitate a strategic communication. This article is using case studies and desk research to study suitable models and communication strategies, which can be applied in the national branding process. It is proposing good practices to bring together research, business, policy making actors and individuals.
\end{abstract}

Keywords: branding, nation branding, strategy, business model, communication JEL:M00, M30, M38, M10, M19

\section{Introduction}

The perception of a service or a product matters often more than the reality. In times of overconsumption it is considered to be tedious and dull to check the quality, therefore brands which are a company's promise to meet a certain standard are helping the customers to differentiate the products (Kotler, 1997). Branding is considered by Williams \& Omar (2014) to be the process through which a brand is established by adding capitalized value to the service or product. Anholt (2008) considers that "branding" is not a method but rather an acquired image. Both visions agree though, that the branding process and the brand are based on positive images, discounting any negative aspects. It is desirable to develop tangible and intangible attributes that increase the differences among services, products, thereby lowering the perceived substitution possibility (Sammut-Bonnici, 2015). 
Nation branding is a concept that has rapidly developed in the past 20 years, as the competitiveness did not only raise on a level of products and services, but also among nations. Trying to attract investment, to increase tourism and to acquire a stable diplomatic position, countries recurred to diverse strategies to differentiate from neighboring leaders or world-wide competitors (Dabija, et al., 2014).

The Bloom Consulting (Bloom Consulting, 2020) assesses every year a brand's increase PICBE | 1006 and decrease in value, considering five factors: attraction of investment, attraction of tourism, attraction of talent, strengthening prominence and strengthening exports. As the nation brand is not only appraised, but it also influences a country's performance in all the five mentioned areas, nation branding grows in importance. The nations listed the first in the 2019/2020 report are USA, Honk Kong, Spain, UK, Australia, Thailand, Italy, Japan and France.

\section{Literature Review}

The national brand is in many ways similar to a product brand, as countries are also involved in a competitive environment in the endeavor to attract investment, businesses and tourists, or in the attempt to exercise political power. Having a strong brand is important, regardless of the development level of a country. It impacts the perception one has of the country, as well as of the products and services produced there, enriching them with credibility, emotion and even feelings.

Unlike the product branding, the nation branding is a more complex process that lasts over a longer period of time and it includes a multitude of stakeholders which should all be equally involved in order to achieve the goal. There is an "infinite range of brand touchpoints associated with the branding of places", therefore there are numerous ways to act. The direction of branding depends on the desire, needs and scope of the parts involved in the collaborative relationship. Even though it is a complex phenomenon that has to be approached from various points of view, more and more countries are willing to follow this path.

The main reason why nations are keen to draw in a different image, is to erase certain elements they are infamous for, to obliterate the memory of historic events or to divert attention from negative reputation. Colombia wants to remove the association with drugs, Germany wants to reconcile after the second world war, even introducing the term "Vergangenheitsbewaltigung" which expresses the struggle to overcome the negative past, Eastern and Central European Countries want to detach from their soviet past (Szondi, 2007). Romania is a country which would benefit of a branding strategy to remove the communist image and help people identify the country by other, more actual and authentic values.

The economic perspective is one of the most common arguments for countries to get involved in branding processes. A strong image attracts foreign investment, facilitates the business development, increases export and raises trust in national products and services. A positive example is Brazil which became "a hot destination for investors" (International Business Publications, 2019), but there are also ineffective examples as Macedonia's capital city, Skopje. The multi-million Euro investment in architecture and infrastructure meant to increase business and tourism was not sufficient, which validates the fact that nation branding is a joint effort.

The tourism industry benefits directly from a solid image and engages in return most of the other economic agents. Countries with solid national brands, for instance Austria, Spain or Portugal, attract millions of tourists every year for the reason that travelers recognize them as attractive, engaging and top destinations.

A consolidated identity attracts citizens to remain in their country, instead of emigrating. This, in turn, assures a lower median age of the population, a greater pool of talented workers and 
the development of universities, as students decide against leaving abroad for studies. A better balance in the age-groups and social categories reduces the expenses with social security and increases the public investments in infrastructure, health system and education. The distinctiveness helps governments strengthen their influence on an international level and improve their reputation.

A forceful brand is therefore advantageous for businesses, governments and individuals but it involves a large group of stakeholders on a local level (town-halls, airports, private sector), b. national level (president, political governance, ministries, NGOs, Commerce Chambers), and c. international level (representatives of the country in international institutions, embassies, cultural institutes, foreign tourist offices).

Although there are many advantages for a country to attempt a nation branding, it can also be a problematic exercise. Gilmore (2002) considers that many country images are not an extension and a development of the true identity, but rather an artificial image, "a fabrication of a false promise". Other authors assume that a country can't be approached as a product, it is "liquid", it faces constant change and reaches a level of complexity that can't be summarized under a brand's name.

Indeed, the image of a country consists of two elements: the real image and the projected image (Picazo \& Moreno-Gil, 2017). A solution to providing a fair image would be the regional branding (Margarisová \& Vokáčová, 2016). Especially applicable for big countries, where the characteristics in some regions differ from others (e.g. India, Russia, USA), but also applicable for countries such as France, which decided to create different brands to appeal to various segments of people and to serve different purposes, e.g. Paris, Val de Loire, Normandy. Additionally, the branding strategy could be considered similar to a political campaign. Therefore, there could appear animosities between the involved stakeholders, when some are interested in an individual goal, rather than the greater good and the initial positive intention might turn into its opposite. Finally, it is a pricy process that has to be sustained for a long period of time, in order to become effective (Anholt, 2008).

As it was pointed out by Andrei (2019), one also has to take into account the wide spreading anti-establishment mood in contemporary societies. Globalization has a divisive effect in terms of disrupting traditions, but also uniting societies through the exchange of similar goods, helping people move and relocate across borders, direct and simultaneous trans-border dialogue and exchange via internet (Andrei, 2019). The same author notes that there is a "global mirroring of the self" (Andrei 2019, p. 304), in the sense of a certain globalization of fears, emotions, expectations, needs and ideas. In terms of relations between public and private actors, one can see that the internationalization of society adds an extra disruptive dimension: global events influence perceptions of public institutions and of markets in which national market leaders or institutional leaders cannot influence. Thus, classical structures of institutions and organizations become obsolete and new type of interactions emerge, which have an effect over the nation branding process. The branding process needs, for example, to consider the risk of fake-news, internet trolling, demystifying myths and preparing some eventual defensive strategy to negative comments.

The essence of political and economic relationships and exchanges is trust. The concept of trust is central in contemporary marketing literature and the challenge of building trust with consumers, constituents and citizens is complex and crucial for profitability and long-term vision. (Andrei, 2018) When consumers are satisfied with a product or a service that they have tried before, they tend to become loyal not only to the product or service, but also to the producer itself, which is perceived as capable of ensuring quality. This so-called "halo effect" (Nisbett \& Wilson, n.d.) is 
applied for countries as well. German products are acknowledged for their quality, therefore even new entries on the market gain quick appreciation for being of "German quality". A recent example of a successful nation branding is UAE. It is a new country that could start with the nation branding from scratch, and that had to secure its position for other reasons than oil \& gas, so UAE became famous for Formula 1, Emirates Airlines, Arsenal Football, cricket, horseraces, golf and film festivals. It is remarkable for high standard at all these level, which is boosting their halo effect.

PICBE $\mid 1008$

Country branding has to take the elements of trust and halo effect into consideration and will have to convince on different levels, the level of economy, of education, of values and of political stability. Public sector and government play an important role in creating a fertile environment for stimulating partnerships and links between private and academia (Blackman and Segal, 1991).

\section{Methodology}

Following a desk research, the authors have analyzed different nation branding strategies, as wel as literature concerning nation branding and relations between various actors in a country and their contribution to building an image. Pursuant to this analysis, the authors are proposing a good practice guide for designing a nation branding. This secondary research is collecting the most effective practices that were used in nation branding strategies, presenting them for the consideration of nations willing to brand or rebrand. This article is particularly concentrated on the business model and management solutions adopted to cluster stakeholders and facilitate their working together.

\section{Discussion}

Based on the models of different countries having realized a successful nation branding, the authors have established a good practice guide for an effective nation branding that could be followed by other countries willing to stabilize its image.

Define the goals: There are specific needs and interests for each country and for those to be achieved, it is imperative to start with a coherent idea of what the brand should express, and which are the objectives to be reached. The nation brand is of significant importance for every stakeholder, therefore different kind of people involved in the branding process might have different visions of the impression that the final brand should convey. To meet the needs and the expectations of everyone involved, the initial stage could be conducted by university researchers who consult and analyze different perspectives and recommend a collective approach.

The relationship between the market and higher education institutions is crucial for the access to skills and knowledge. The relationship process is complex, containing both a sciencepush and a demand-pull. The intertwining flows between science, technology, marketplace and academia indicate a non-linear, interactive innovation process with multiple communication and knowledge transfer between firms, individuals, suppliers, tourism agencies, governments and researchers. The essential role played by the communication and transfer of knowledge makes clear the importance of the human dimension in the economic activity. In current society, knowledge has a short-lived "shelf-live", therefore it is skills that start to take the upper hand as a vital ingredient in economic success. This creates an increased pressure to form partnership between both private and public sector and academia, as both aforementioned sectors are dependent upon the ability to acquire well-trained and skilled employees, receiving appropriate training for their existing employees, as well as getting innovative research results. Moreover, as the cost of R\&D 
increases, companies have to enter into partnership, either with competitors or with universities, in order to achieve a competitive edge. In the aftermath of globalization, academic bodies which understand the difference between nations and markets or make comparative research analysis gain in value. (Blackman and Segal, 1991)

The brand should be built on a main idea: A nation brand is compounded by a series of elements that are related to the target country, but it has to remain unequivocal to be forceful. If PICBE | 1009 the entire perspective can't be reduced to a sole detail, the brand won't be able to address the desired message to the right people. As the main brand element is a merge between the desires of the leading partners embroiled in the process as showed in Figure 1, with the input of additional stakeholders, those parties have to be represented and involved in the decision-making process. It is ambitious to define the identity of a nation by staying limited to one attribute, reason for which many branding processes fail before being applied and other are abandoned, as they don't reflect everyone's viewpoint. To keep up with the dynamic character of a nation, some countries have decided to change their branding once a few years to communicate a prevailing particularity. In case of bigger nations with distinct regions, whose identity can't converge to a main idea, but rather diverges in creating a possible conflict of interests, the possibility of dividing a nation brand into disparate regional brands should be considered.

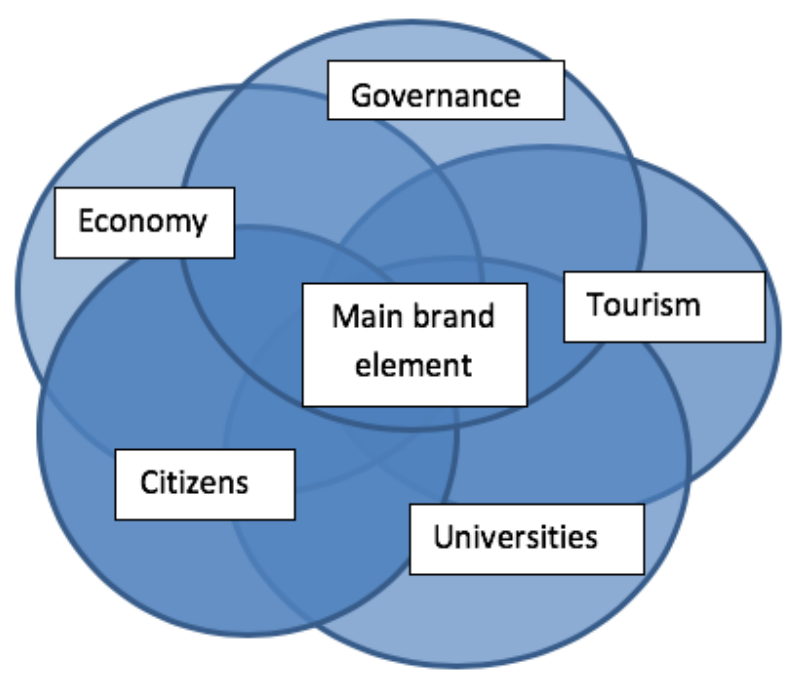

Figure 1: Main stakeholders to contribute to the brand creation process

Source: Adapted from (Anholt, 2008)

Consider the current standing: Once the goal is defined, the current standing of the country should be clarified. The aspects that should be taken into consideration are related to the actual national brand, including information about the attributes comprised in Table 1 below, which are, according to Gallarza, et al., (2002), part of the destination image.

Table 1: Attributes to be considered for nation branding 

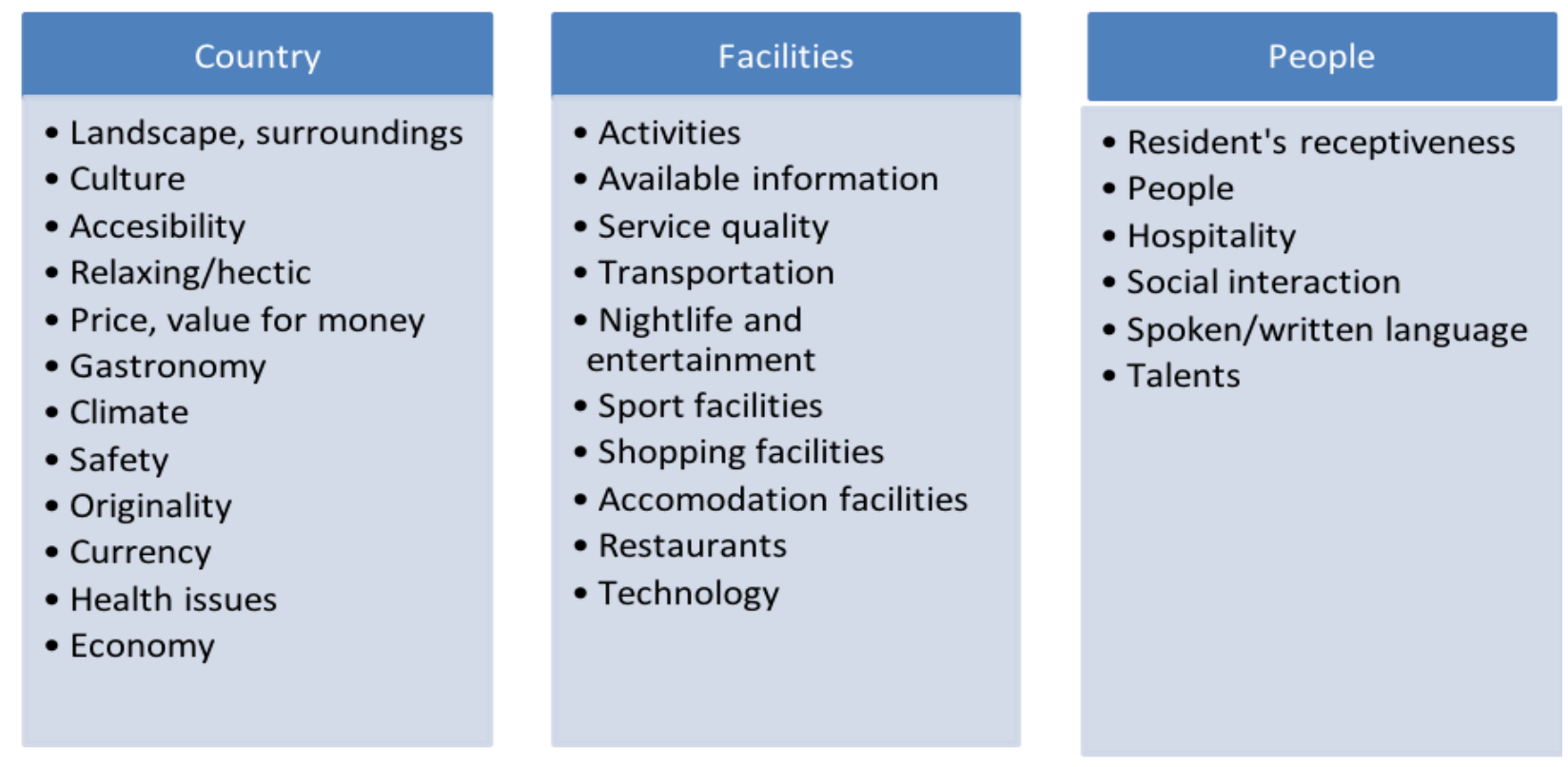

PICBE | 1010

Source: Adapted from (Place Brand Observer, 2015) and (Gallarza, et al., 2002)

The branding of a country will not succeed if that respective country does not make good use of financial resources, a task virtually impossible without the implication of public institutions (at legislative, executive and judiciary level), that work in an accountable, transparent and efficient manner (Uphoff, Krishna 2004). This has a domino effect on other areas of society, such as business, academia and civil society enabling them to articulate demands, as well as defend their interests and rights. Uphoff and Krishna make an inventory of institutions and entities relevant in the good functioning of a country and its civil society, namely: the executive, the legislative, the judiciary, the national, regional and local administrations, the armed forces and the police, the business, the academia, the media, the non-profit sector, the trade unions and the religious organizations. Their diversity is significant in terms of the complexity of relationships needed in order to achieve a smooth administration and set the foundations of an authentic country branding.

Branding is dependent upon public perception. Although often neglected, perception and interpretation are as important as the communication strategy itself (Myers and Russell, 2019). Patterns of congruity and discrepancy in channels of communication are sometimes counterintuitive, in particular in cases of political stability and credibility of a country. For example, not all-congruous communication is beneficial, neither all discrepancies are detrimental, as the research carried out by Grebelsky and Lichtman (2016) highlighted. On basis of communication patterns in electoral campaigning, the researchers discovered that the winning candidates employed an adaptive discrepancy strategy characterized by strong, challenging verbal affirmations, including accusations and threats, coupled with a composed, calm and sometimes smiling nonverbal stance. The opposite strategy, called leakage discrepancy, characterized by positive, reliable and ethical speech, coupled with negative non-verbal communication proved to be counterproductive because it suggested evasiveness, insincerity or ambiguity. Further on, the research of Cwalina and Drzewiecka (2019) show that leadership styles that are appreciated in our society are combining competence and integrity, capacity to build bonds and harmony, as well as understanding of people's needs, which does not have to mean populism. On a wider scale, these 
are also patterns for countries with successful branding in terms of political stability, predictability and credibility.

Political country branding makes use, in addition to credibility elements, of symbolic, evocative images, like flags and archetypes, to trigger an emotional response, avoiding to rely only on pure facts, direct address and non-evocative images (Page and Duffy, 2018; Brader, 2006).

Implementation process: The implantation is the most complex phase of development. It PICBE | 1011 relies on both branding products and appropriate communication. As there are various stakeholders involved in the process, it is required to have a leading organization to coordinate the process and to track the progress. In order to stay neutral and to equally represent the needs, a self-standing organization is the most useful solution.

It is legitimate to ask ourselves about the correlation between the sustainability efforts of a country and their branding success. Environmental concerns are supported by politically engaged institutions, appropriate academic research and responsive Corporate Social Responsibility initiatives. However, the countries outlined among the successful performers in our tables below do not seem to excel in sustainability considerations. Farmer et al. (2017) found out in an experiment study, that consumers use products differently, namely they consume less of a sustainable product than of an equivalent traditional product. Therefore, an increase in sustainability seems to bring along a decrease in consumption, a highly relevant goal for greenminded public institutions of developed countries. A positive correlation between sustainability and country branding was not yet consistently found to our knowledge and it is a field worthy of further exploration.

A further area of exploration in the issue of country branding is the relationship between the branding and religion or God perception of the respective country. A surprising correlation was found between sustainability behavior and the citizen's representation of God and godly attributes, such as an authoritative, benevolent or mystical nature. The mystical representation of God seems to bring along a positive influence and support for sustainability, for example (Johnson et al., 2017). Influence of religion over branding is therefore another area of exploration.

Inspiration from good performers: A good-practice model of implementation in Europe is Enterprise Estonia (EAS), which is responsible for nation branding in Estonia and is one of the most effective models. It is a self-standing organization with approximately 266 employees who represent 600 stakeholders. They are providing guidance, consultancy, financial assistance and support for enterprises, public and non-profit organizations as well as research institutions (Enterprise Estonia, n.d.).

The fastest growing country brand in Central American which represents a successful example is Essential Costa Rica. The main element they've built the strategy on is the leading position in renewable energy. Similar to Estonia, they have built a self-standing organization, which acts like an aggregator for the most important aspects embedded in their nation brand and identity. Very much business oriented, they promote their national brands and help those develop and gain a worldwide recognition. The brands are divided into the following categories: food, agriculture, specialized industries and service industry, tourism, and each category is run by representatives. Costa Rica brand is considering the following elements in the development: culture, exports, geography, government, history, infrastructure, investment, environment, talents and tourism.

The third success example is Turkey, a country which with a remarkable history and different patterns of a regional significance. In recent years, Turkey started a new branding campaign, called "Discover the potential" (The relationship between global competitiveness, 
international market share, and country's brand image, with implications for Turkey, 2015). This initiative is proceeding other campaigns initiated in the past by ministries, each one following being able to involve even more faithfully the complex character of the state. Examples of previous campaigns are: "Turkey welcomes you", or "More is always on the way". Being innovative and able to change, Turkey managed to corroborate the work of civil authorities, academics and business professionals. The participation of the three segments lends credibility to the local products and services, therefore Turkey has built partnerships all-over the world, local brands and products are exported in over 200 countries and yearly over 50 million (Turkish Statistical institute, 2020) tourists cross their border.

\section{Conclusion}

Nation branding effects are not immediately visible. Sometimes it might take years before the results of a change is visible. It requires a sustained effort and investment and nevertheless the most challenging part is the ability to have the stakeholders work together. Following the example of Estonia and Costa Rica, a self-standing organization is the most useful way to lead and manage a nation brand. Also, it is important to notice that the nation brand should be genuine and accurate to generate the wished results. Therefore, the model of Turkey, which has changed the identity over time, is an applicable example. As countries started to be cognizant of the value of their brand, the effort to brand a nation is more widely undertaken, despite the difficulties. For further studies, each country interested in nation branding should consider a form of business model that works applied on their specificity. By translating these results to other countries, like the country that the researchers know best, Romania, we conclude that it would benefit from a coherent nation branding in terms of investment, economic growth, infrastructure, tourism and quality education, but also from increase in the coherence of relationships between stable institutional and legislative process, potent judiciary and business friendly conditions.

\section{References}

Andrei, C. (2018) The Political Marketing of Broken Trust, Journal of Political Marketing, 17(2), $176-192$.

Andrei, C. (2019) Exchanging Political Value: The Global Layer in Political Marketing, Journal of Political Marketing, 18(4), 303-306

Anholt, S. (2008). Place branding: Is it marketing, or isn't it?. Place branding and Public Diplomacy, 4(1), 1-6.

Balkanli, M. B. (2015), The relationship between global competitiveness, international market share, and country's brand image, with implications for Turkey - doctoral dissertation research.

Blackman, C. \& Segal, N. (1991) Access to skills and knowledge: managing the relationships with higher education institutions, Technology Analysis \& Strategic Management, 3(3), 297-303

Brader, T. (2006). Campaigning for Hearts and Minds: How Emotional Appeals in Political Ads Work. Chicago: University of Chicago Press.

Cwalina, W. \& Falkowski, A. (2018) Crisis Management: Government Strategy in Framing Reform Proposals and Communications, Journal of Political Marketing, 17(2), 122-136

Cwalina, W. \& Drzewiecka, M. (2019) Who Are the Political Leaders We Are Looking for? Candidate Positioning in Terms of Leadership Style. A Cross-Cultural Study in Goleman's Typology, Journal of Political Marketing, 18(4), 344-359.

Dabija, D.C., Postelnicu, C. \& Pop, N. Al. (2014) Methodology for assessing the degree of internationalisation of business academic programmes, Amfiteatru economic, 16(37), 726745 
Enterprise Estonia, n.d. Enterprise Estonia. Retrieve from https://www.eas.ee/eas/?lang=en

Gallarza, M., Saura, I. \& Garcia, H., 2002. Destination Image. Annals of Tourism Research, 29(1), (56- $(78$.

Farmer, A., Breazeale, M., Stevens, J. L. \& Waites, S. F. (2017): Eat Green, Get Lean: Promoting Sustainability Reduces Consumption, American Marketing Association Journal of Public Policy \& Marketing, 36(2), 299-312

PICBE $\mid 1013$

Gilmore, F. (2002). A country - can it be repositioned? Spain - the success story of country branding. Journal of Brand Management, 9(4-5), 281-293.

International Business Publications, (2019). Brazil, Doing business, Investing in Brazil Guide. s.1.:International Business publication USA Washington DC.

Journal of Political Marketing, 18:1-2, 148-177,

Johnson, K. A., Liu, R. L., Minton, E. A., Bartholomew, D. E., Peterson, M., Cohen, A. B. \& Kees. J. (2017). Citizens' Representations of God and Support for Sustainability Policies, American Marketing Association Journal of Public Policy \& Marketing, 36(2), 362-378.

Kotler, P. (1997). Marketing Management. s.1.:Prentice Hall:Upper Saddle River.

Margarisová, K. \& Vokáčová, L. (2016). Regional Branding: Building Brand Value, Acta Universitatis Agriculturae Et Silviculturae Mendelianae Brunensis, 64(6), 2059-2066.

Myers, C. \& Russell, K. (2019) Image repair in the aftermath of inaccurate polling: How the news media responded to getting it wrong in 1948 and 2016, Journal of Political Marketing, 18:1$2,148-177$.

Nisbett, R. \& Wilson, T. D. W., n.d. The Halo Effect: Evidence for Unconscious Alteration of Judgments. Journal of Personality and Social Psychology, 35(4), 250-256.

Page J. T. \& Duffy, M. E. (2018) What Does Credibility Look like? Tweets and Walls in U.S. Presidential Candidates' Visual Storytelling, Journal of Political Marketing, 17(1), 3-31

Picazo, P. \& Moreno-Gil, S. (2017). Analysis of the projected image of tourism destinations on photographs: A literature review to prepare for the future, Journal of Vacation Marketing, 25(3).

Place Brand Observer, (2015).Place branding in 5 steps. A guide on how to build successful place. Retrieved form: https://placebrandobserver.com/five-step-place-branding-approach/

Society for Human Resource Management (2019): The global skills shortage. Bridging the Talent Gap with Education, Training and Sourcing, Retrieved from: https://www.shrm.org/hrtoday/trends-and-forecasting/research-and-surveys/

Szondi, G., (2007). The role and challenges of country branding in transition countries: The Central European and Eastern European experience. Place Branding and Public Diplomacy, 3(1), $8-20$.

Turkish Statistical institute, 2020. s.1.: Turkish Statistical institute.

Uphoff, N. \& Krishna, A. (2004). Civil Society And Public Sector Institutions: More Than A ZeroSum Relationship, Public administration and development, 24, 357-372

Williams, R. L. \& Omar, M. (2014). How branding process activities impact brand equity within Higher Education Institutions. Journal of Marketing for Higher Education, 24(1), 1-10. 